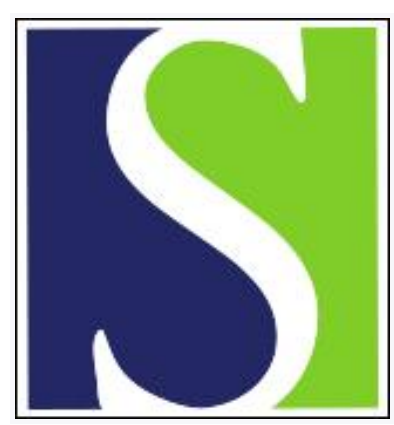

Scand J Work Environ Health 1980;6(1):19-32

https://doi.org/10.5271/sjweh.2636

Issue date: Mar 1980

Symptoms of car painters with long-term exposure to a mixture of organic solvents.

by Husman $\mathrm{K}$

Key terms: car painter; exposure; health selection; long-term exposure; organic solvent; subjective symptom; symptom

This article in PubMed: www.ncbi.nlm.nih.gov/pubmed/7384765

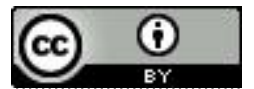




\title{
Symptoms of car painters with long-term exposure to a mixture of organic solvents
}

\author{
by Kaj Husman, MD ${ }^{1}$
}

\begin{abstract}
HUSMAN K. Symptoms of car painters with long-term exposure to a mixture of organic solvents. Scand $j$ work environ health 6 (1980) 19-32. Symptoms as an early sign of the effect of low-level exposure to organic solvents were studied among 102 male car painters and 102 referents with the aid of a symptom questionnaire. The exposure level was about one-third of the current administrative threshold limit value recommended in Finland. In addition to the comparisons of the appearance of single symptoms among the exposed and reference groups partial correlation and factor analyses were performed. Symptoms of fatigue and disturbances in memory and vigilance occurred statistically significantly more often among the exposed than among the referents. When the symptoms during the workshift (acute symptoms) were compared, irritation symptoms and "prenarcotic" symptoms were reported significantly more often in the exposed group. Correlation and factor analyses of the acute symptoms among the car painters suggested that acute symptoms are related at the individual level, as hypothesized on the basis of earlier literature. By means of a questionnaire sent to 124 men who changed employment in the 5 a before this investigation, it was found that health was an important reason for having left the car painting trade for those who had taken jobs without exposure to organic solvents. This finding indicates that those car painters included in this study may have undergone some degree of health selection. The results suggest that a symptom inquiry is helpful for detecting the possible early effects of exposure to a mixture of organic solvents.
\end{abstract}

Key terms: car painters, health selection, long-term exposure, organic solvents, subjective symptoms.

Although mixtures of solvents are commonly used in many occupations $(3,6,7$, 20, 24), few controlled studies concern their health effects in long-term occupational exposure.

The most common symptoms reported in studies of workers chronically exposed to different organic solvents are unusual tiredness, concentration difficulties, impaired memory, and dizziness $(7,9,10,15$, 18, 19). In addition Cianchetti et al (4) have described 122 cases of polyneuropathy; they listed the following symptoms: anorexia, nausea and vomiting, epigastric pain, headache, dizziness, and insomnia. In most

1 Kuopio Regional Institute of Occupational Health, Kuopio, Finland.

Reprint requests to: Dr Kaj Husman, Kuopio Regional Institute of Occupational Health, Kauppakatu 59-61, SF-70100 Kuopio 10, Finland. of these studies the exposure level was quite high $(4,15,19)$, the studied populations small $(7,18)$, or a reference group missing (4).

Reports are lacking concerning the effects of long-term exposure to low levels of organic solvent mixtures on symptoms in relation to threshold limit values (TLVs). My colleagues and I have studied the various health effects of such exposure among car painters, and we have reported the psychological, neurophysiological, and neuroophthalmological findings elsewhere $(8,25,26)$. The objectives of this part of the study were (i) to determine the symptoms of workers occupationally exposed to a mixture of organic solvents in a comparison with a reference group, (ii) to test the usefulness of a questionnaire on symptoms in revealing early signs of the chronic influence of solvents on the nervous system, 
and (iii) to determine the extent to which subjective health disturbances due to organic solvent exposure cause workers to leave car painting work.

\section{Material and methods}

\section{Subjects}

The exposed subjects comprised 102 male car painters from 27 (out of 29) car repair garages in Helsinki in 1974. They were drawn from all active car painters in Helsinki $(\mathrm{N}=166)$ by stratified sampling so that subjects with different exposure times became represented as evenly as possible (table 1). The duration of exposure of these subjects ranged from 1 to 40 a (mean 14.8, SD 8.5), and the age from 20 to 65 a (mean 35, SD 11). Three of the exposed subjects were $\mathbf{5 5}$ a or older.

The reference group was chosen from locomotive engineers and assistants of the Finnish State Railways. They were agematched with the exposed subjects. However, there were no referents older than 54 a available because the age of retirement is $\mathbf{5 5}$ for these occupations. Half of the reference group consisted of engineers and the other half of assistants. Irregular shift work and mental stress are the most important factors affecting subjective symptoms in railroad work (11).

For studying the effect of selection due to health, a questionnaire was sent to all the men $(\mathrm{N}=124)$ who had left a car painting job in the 27 car repair garages involved in the study during the 5 a preceding the investigation (from 1 January 1969 to 31 December 1973).

Table 1. Number of car painters in Helsinki and the sample according to duration of exposure.

\begin{tabular}{ccc}
\hline $\begin{array}{c}\text { Duration of } \\
\text { exposure } \\
\text { (a) }\end{array}$ & $\begin{array}{c}\text { Car painters } \\
\text { in Helsinki }\end{array}$ & $\begin{array}{c}\text { Car painters } \\
\text { in the sample }\end{array}$ \\
\hline $1-5$ & 37 & 21 \\
$6-10$ & 44 & 21 \\
$11-15$ & 45 & 20 \\
$16-20$ & 15 & 15 \\
$21-25$ & 11 & 11 \\
$\geq 26$ & 14 & 14 \\
\hline Total & 166 & 102 \\
\hline
\end{tabular}

\section{Exposure}

The main constitution of the binders, solvents and other components of the paints used in car painting is listed in table 2 .

Solvent concentrations were measured in the air of six randomly selected car repair garages, which employed a total of 40 car painters. The range of concentrations of separate components was 4 to $212 \%$ of the respective Finnish recommended administrative TLVs, which correspond to the TLVs recommended by the American Conference of Governmental Hygienists (ACGIH) (1). The variation of the $1-h$ average concentrations during a workday was evaluated by repeated sampling. Because the exposure has already been described in detail $(8,25)$, only a brief summary is included in this report (table 3).

There were no marked differences in the work conditions and the type of solvent exposures of the six car repair garages since the work methods, ventilation equipment, and paints used were essentially the same. Because of the small variation of the exposure in different garages and the random sampling method applied, it was assumed that the six car repair garages were representative of all the 27 car repair garages which employed the exposed workers (all garages were visited, however).

The median age of the car repair garages was $15 \mathrm{a}$ and the ventilation installations were about 10 a old. This finding, and the fact that paint solvents have been the same for 20 a indicated that the exposure had been at about the same level for at least the last 10 a.

\section{Symptom survey}

The questionnaire used in the symptom survey was divided into two parts, ie, one concerning general symptoms $(\mathrm{N}=26)$ and another concerning acute symptoms during the workshift $(\mathrm{N}=11)$, altogether 37 questions. The questions dealing with general symptoms were formulated so that they covered symptoms revealed in earlier studies on solvent exposure, ie, unusual tiredness, fatigue, sleeping difficulties, impaired memory, concentration difficulties, 
vegetative symptoms, disturbances in vigilance, dizziness, and symptoms of peripheral neuropathy $(2,3,7,9,10,16,22,27)$. Acute symptoms were probed with questions about irritation of the mucous membranes and skin, and the "prenarcotic" effects of solvents $(15,18,19,23)$. In the symptom survey background variables which could have influenced subjective symptoms were also inquired about, ie, education, use of alcohol and medicines, smoking habits, and head trauma.

A three-step rating scale (never, sometimes, often) was used in the questionnaire, which was constructed in a language that was simple and unambiguous in order to facilitate answering. The same questions had been used in an investigation of styrene-exposed workers (9), except those on alcohol consumption which were standardized questions developed in the Finnish Social Research Institute of Alcohol Studies (21).

The subjects filled out the questionnaire themselves at home before the clinical part of the investigation, and an interviewer checked their answers. In the questionnaire sent to the 124 men who had left a car painting job between 1 January 1969 and 31 December 1973, the questions concerning acute symptoms were the same, but questions were added concerning rea-

Table 2. Constitution of the exposure of the car painters.

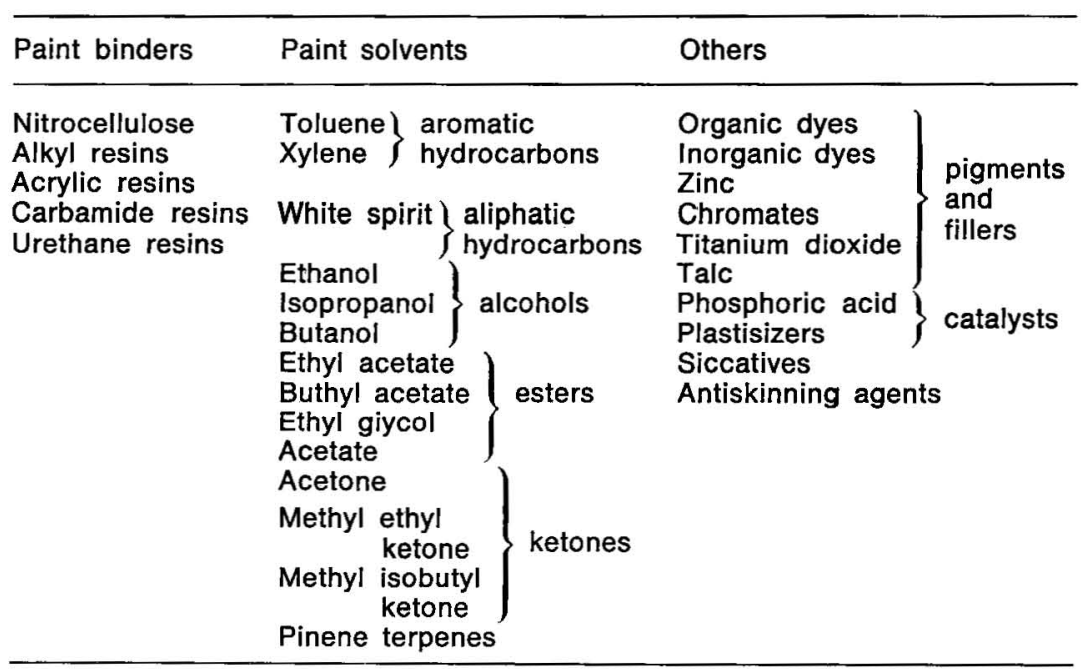

Table 3. Mean concentrations of organic solvents in the breathing zone of 40 car painters. (Sampling period $=1 \mathrm{~h}$; number of car repair garages $=6$; number of samples $=54$ ).

\begin{tabular}{|c|c|c|c|c|}
\hline Solvent & $\begin{array}{c}\text { Mean concen- } \\
\text { tration } \\
\left(\mathrm{ppm} \text { or } \mathrm{cm}^{3} / \mathrm{m}^{3}\right)\end{array}$ & $\begin{array}{c}\text { Range } \\
\left(\mathrm{ppm} \text { or } \mathrm{cm}^{3} / \mathrm{m}^{3}\right)\end{array}$ & $\begin{array}{c}\text { Percentage of } \\
\text { the TLV a }\end{array}$ & $\begin{array}{c}\text { TLV a } \\
\left.\text { (ppm or } \mathrm{cm}^{3} / \mathrm{m}^{3}\right)\end{array}$ \\
\hline $\begin{array}{l}\text { Toluene } \\
\text { Xylene } \\
\text { Butyl acetate } \\
\text { White spirit } \\
\text { Methyl isobutyl ketone } \\
\text { Isopropanol } \\
\text { Ethyl acetate } \\
\text { Acetone } \\
\text { Ethanol }\end{array}$ & $\begin{array}{r}30.6 \\
5.8 \\
6.8 \\
4.9 \\
1.7 \\
2.9 \\
2.6 \\
3.1 \\
2.9\end{array}$ & $\begin{array}{r}5-249 \\
<1-36 \\
<1-128 \\
<1-150 \\
<1-39 \\
<1-85 \\
<1-14 \\
<1-25 \\
<1-27\end{array}$ & $\begin{array}{r}15.3 \\
5.8 \\
4.5 \\
2.5 \\
1.7 \\
0.7 \\
0.7 \\
0.3 \\
0.3\end{array}$ & $\begin{array}{r}200 \\
100 \\
150 \\
200 \\
100 \\
400 \\
400 \\
1,000 \\
1,000\end{array}$ \\
\hline Total & & & 31.8 & nge $4-212 \%$ ) \\
\hline
\end{tabular}

a $\quad$ TLV $=$ recommended threshold limit value in Finland in 1974. 
sons for leaving the job and information about current employment if not retired (fig 1).

\section{Statistical methods}

In the pairwise comparison the sign test was used to compare the subjective symptoms of the exposed and nonexposed groups symptom by symptom.

Symptoms (acute) connected to car painting during the workday were also analyzed for interrelations. The following statistical procedure was employed:

1. For corresponding symptoms, the answers of the car painter and his referent were coded by the alternatives 1 ("never"), 2 ("sometimes") and 3 ("often"), and pairwise differences with possible values of $-2,-1,0,1$ and 2 were formed. These values were used for the variables in the calculation of the Pearson correlation coefficients. The use of pairwise differences was applied in order to diminish the confounding effects of the presumably different age trends of the symptoms.

2. From the primary correlation matrix between eight variables, all sixth-order partial correlations were calculated (13). Correlation analysis clarifies the true pairwise associations.

3. The primary correlation matrix was factorized by means of a principal factor solution, and the factor structure was simplified with a Varimax rotation.

\section{Comparability of the groups}

The referents had a somewhat higher education than the car painters. Only 34 car painters had completed training in a vocational school, while all locomotive engineers attend the special school run by the Finnish State Railways.

The answers to the questions concerning frequency of alcohol consumption and the amount of alcohol used were similarly distributed in both groups. The mean frequency of alcohol use was, in both groups, between once a week and twice a month. It appeared that their tolerance to alcohol had decreased.

Fourteen car painters and 13 referents used medicines regularly, and 13 car painters and 24 referents temporarily. There were only insignificant differences in smoking habits between the exposed subjects and the referents. The number of

INQUIRY TO THOSE WHO HAD CHANGED EMPLOYMENT

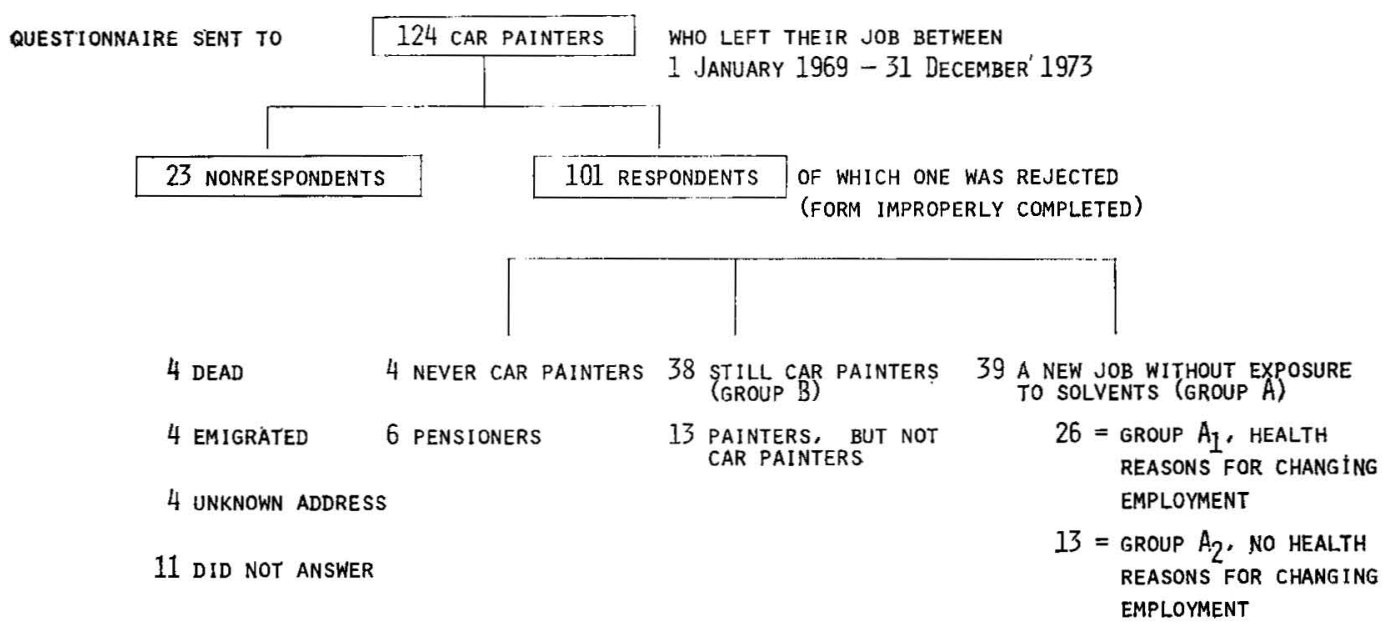

TOTAL $23 \quad 10 \quad 51 \quad 39$

Fig 1. Description of the nonrespondents and respondents to the questionnaire sent to past employees of the car repair garages in the study. 
workers with a history of latent diabetes (no medication), epilepsy, past tuberculosis with medication taken for less than 1 a, and cerebral contusion (consciousless about $30 \mathrm{~min}$ ) appear in table 4 .

\section{Results}

\section{General subjective (chronic) symptoms}

The questions concerning chronic symptoms are shown in table 5. The car painters had more symptoms of fatigue, concentration difficulties, and disturbances in vigilance than the engineers (table 5). For example, 25 of the car painters "often felt excess tiredness after the workday," while only 11 of the referents reported the same symptom. Twenty-four car painters "often forgot things easily," but only five of the referents had the same problem.

The exposed subjects and the referents did not differ essentially in their answers to questions concerning headache, sleeping difficulties, lability of mood, symptoms of peripheral neuropathy, and vegetative symptoms.

The results of a pairwise comparison of the chronic symptoms appear in table 6 . Statistically significant differences occurred for fatigue and concentration difficulties.

The symptoms which were more prevalent among the car painters were evaluated for variation related to length of exposure. Those listed in table 6 were chosen, and the means and standard deviations of the length of exposure were computed for all of these symptoms. The groups were formed so that the men in group 1 had a lower symptom level than their referents, the symptom level of the men in group 2 was the same as their referents, and that of the men in group 3 was correspondingly higher. The variations between the group means were small and not statistically significant. The mean exposure times, eg, for the symptom "forgetting things easily," were 13.3, 13.8 and 16.6 a, respectively, and they were even less for the other symptoms. The small differences hint to the influence of the selective effect of job turnover. Because the detection of the harmful effects of work conditions on workers (and the influence of job turnover) is based more on acute symptoms than on chronic ones; the acute symptoms were also evaluated with respect to length of exposure (see the section on symptoms during the workday).

\section{Symptoms during the workday (acute symptoms)}

Table 7 lists the questions on the acute symptoms of car painters and their referents. These symptoms could be divided a priori into two groups: irritation symptoms and "prenarcotic" symptoms (9). A pairwise comparison of the acute symptoms appears in table 8 .

During the workday, irritation and "prenarcotic" symptoms were especially present in the exposed group (tables 7 \& 8). Itching, nausea, a drunken feeling, dizziness, and absentmindedness were common complaints among the car painters. Also shortness of breath was more common among them than among the referents.

The effect of the duration of exposure on the experienced acute symptoms was scrutinized (table 9). In order to eliminate the possible effect of ageing, this consideration was made for pairwise differences, 'but the score totals of only six acute symptoms were used. For reasons mentioned later, "drunken feeling" and "misunderstanding of given orders" were excluded. In the scoring "never" corresponds to 1, "sometimes" to 2 , and "often" to 3 . The dependence of the difference totals on the duration of exposure was irregular, and it has been discussed with respect to selection.

Table 4. Diseases with possible effects on some symptoms among the car painters and the referents.

\begin{tabular}{lcc}
\hline Disease & $\begin{array}{c}\text { Car painters } \\
(\mathrm{N}=102)\end{array}$ & $\begin{array}{c}\text { Referents } \\
(\mathrm{N}=102)\end{array}$ \\
\hline Diabetes & 1 & 1 \\
Diabetes + epilepsy & 1 & $\frac{1}{2}$ \\
$\begin{array}{l}\text { Tuberculosis } \\
\text { Cerebral contusion }\end{array}$ & 2 & - \\
$\begin{array}{l}\text { Paresis of right leg after } \\
\text { sciatic nerve lesion }\end{array}$ & 1 & 1 \\
Neurotic disorders & - & 1 \\
\hline
\end{tabular}


Table 5. Responses indicating general (chronic) symptoms among the car painters $(\mathrm{N}=102)$ and referents $(N=102)$. ${ }^{a}$ The questions have been translated from Finnish.

\begin{tabular}{ccccc}
\hline \multirow{2}{*}{ Symptom } & \multicolumn{2}{c}{ Response } & & Often \\
\cline { 2 - 3 } & $\begin{array}{c}\text { Car } \\
\text { painters Referents }\end{array}$ & $\begin{array}{c}\text { Car } \\
\text { painters Referents }\end{array}$ & $\begin{array}{c}\text { Car } \\
\text { painters Referents }\end{array}$ \\
\hline
\end{tabular}

1. Symptoms of fatigue

Do you feel excess tiredness after the workday?

Do you get up tired

18

24

in the morning?

2. Concentration difficulties

Do you forget things easily?

Do you easily forget what you intended to do or say?

Do your thoughts stray when you try to concentrate?

Do you fall asleep when watching television?

Do you easily fall into your own thoughts?

3. Sleeping difficulties

Do you have difficulty falling asleep?

Do you have difficulty staying asleep?

Do you have nightmares?

4. Lability of mood

Does your mood change without reason?

Are you depressed?

Are you irritated?

Are you restless?

Are you afraid?

Are you listless?

Are you drowsy?

Do you become tired among other people?

Do you have difficulties in starting a natural discussion with others?

5. Headache and dizziness

Do you have persistent or recurrent headache?

Do you have spells of dizziness?

Do you have persistent dizziness?

\section{Vegetative symptoms}

Do you sweat easily?

Are you bothered by your heart pounding?

Do your hands tremble?

9

16

36

49

25

31

34

46

45

43

20

37

64

32

35

44

28

51

78

94

29

65

65
87

101

68

26

64

55

33

28

37

23

6

60

62

52

41

42

71

49

33

57

43

53

55

55

24

5

6

55

23

13

8

36

15

19

5

58

8

24 
Table 5. (continued)

\begin{tabular}{|c|c|c|c|c|c|c|}
\hline \multirow{3}{*}{ Symptom } & \multicolumn{6}{|c|}{ Response } \\
\hline & \multicolumn{2}{|c|}{ Never } & \multicolumn{2}{|c|}{ Sometimes } & \multicolumn{2}{|c|}{ Often } \\
\hline & $\begin{array}{c}\text { Car } \\
\text { painters }\end{array}$ & Referents & $\begin{array}{c}\text { Car } \\
\text { painters }\end{array}$ & Referents & $\begin{array}{c}\text { Car } \\
\text { painters }\end{array}$ & Referents \\
\hline $\begin{array}{l}\text { Do your feel like you have } \\
\text { something in your throat? }\end{array}$ & 55 & 67 & 43 & 30 & 4 & 5 \\
\hline \multicolumn{7}{|c|}{ 7. Symptoms of peripheral neuropathy } \\
\hline $\begin{array}{l}\text { Do your legs feel numb } \\
\text { or tingle? }\end{array}$ & 73 & 70 & 7 & 5 & 4 & 5 \\
\hline
\end{tabular}

a For a pairwise comparison of the symptom level and the statistical significance of the difference, see table 6 . Symptoms not listed in table 6 did not differ statistically significantly.

Table 6. Results of a pairwise comparison of the chronic symptoms of the 102 age-matched pairs of exposed (car painters) and reference (locomotive engineers and assistants) subjects. (A: the car painters experienced symptoms more frequently than the referents; $B$ : the referents experienced symptoms more frequently than the car painters)

Symptom

$\frac{\text { Cases }}{\text { A }}$ B $\quad \begin{gathered}\text { Level of significance } \\ \text { of difference a (p-value) }\end{gathered}$

\section{Symptoms of fatigue}

Do you feel excess tiredness after the workday?

Do you get up tired in the morning?

$\begin{array}{lll}34 & 18 & <0.05 \\ 36 & 23 & <0.1 \\ & & \\ 35 & 19 & <0.05 \\ 38 & 12 & <0.001 \\ 42 & 10 & <0.001 \\ 40 & 19 & <0.01\end{array}$

Concentration difficulties

Do you fall asleep when watching television?

Do you forget things easily?

Do you easily forget what you intended to do or say?

Do you easily fall into your own thoughts?

a Sign test.

\section{Associations between acute symptoms}

The correlation matrix achieved with the pairwise differences of the symptom scores is presented in table 10. During the first stage of the structure association analysis, the partial correlation coefficients were calculated. The results are presented in table 11.

The orthogonal factor pattern achieved with the principal factor solution and the simplified structure after the Varimax rotation appears in table 12 .

The results of the factor and partial correlation analyses showed that the following symptom complexes were experienced often:
1. Nausea with attacks of vomiting and dizziness

2. Absentmindedness and misunderstanding of given orders

3. Nausea and a drunken feeling

4. Nausea and misunderstanding of given orders.

The partial correlation between nausea and the misunderstanding of given orders was highly significant, and it detected the connection more clearly than the results of the chosen rotation for factor solution. It is possible that the combination shortness of breath and absentmindedness should be added to the list above, but it could have just as well appeared randomly.

Itching was not consistently related to the other symptoms. 
Table 7. Responses concerning symptoms during the workshift (acute symptoms) among the car painters $(N=102)$ and referents $(N=102)$ a The questions have been translated from Finnish.

\begin{tabular}{|c|c|c|c|c|c|c|}
\hline \multirow[b]{2}{*}{ Symptom } & \multicolumn{2}{|c|}{ Never } & \multicolumn{2}{|c|}{ Sometimes } & \multicolumn{2}{|c|}{ Often } \\
\hline & $\begin{array}{c}\text { Car } \\
\text { painters }\end{array}$ & Referents & $\underset{\text { painters }}{\text { Car }}$ & Referents & $\begin{array}{c}\text { Car } \\
\text { painters }\end{array}$ & Referents \\
\hline \multicolumn{7}{|l|}{ Irritation symptoms } \\
\hline $\begin{array}{l}\text { Are you bothered by } \\
\text { itching? }\end{array}$ & 47 & 65 & 47 & 33 & 8 & 4 \\
\hline \multicolumn{7}{|l|}{ Prenarcotic symptoms } \\
\hline Do you feel nauseated? & 53 & 73 & 41 & 29 & 8 & 0 \\
\hline $\begin{array}{l}\text { Do you have attacks of } \\
\text { vomiting? }\end{array}$ & 79 & 93 & 21 & 9 & 2 & 0 \\
\hline $\begin{array}{l}\text { Do you have spells of } \\
\text { dizziness? }\end{array}$ & 69 & 90 & 28 & 11 & 5 & 1 \\
\hline $\begin{array}{l}\text { Do you have a drunken } \\
\text { feeling? }\end{array}$ & 60 & 99 & 41 & 3 & 1 & 0 \\
\hline Do you have a headache? & 40 & 46 & 50 & 46 & 12 & 10 \\
\hline Are you short of breath? & 76 & 94 & 21 & 7 & 5 & 1 \\
\hline $\begin{array}{l}\text { Do you feel absentminded } \\
\text { or are you buried in your } \\
\text { thoughts? }\end{array}$ & 27 & 59 & 58 & 41 & 17 & 2 \\
\hline $\begin{array}{l}\text { Do you easily misunder- } \\
\text { stand orders given to } \\
\text { you? }\end{array}$ & 62 & 87 & 35 & 15 & 5 & 0 \\
\hline $\begin{array}{l}\text { Do you hear tingling in } \\
\text { your ears? }\end{array}$ & 58 & 63 & 32 & 33 & 12 & 6 \\
\hline $\begin{array}{l}\text { Have you had difficulties } \\
\text { with spelling or "talking } \\
\text { like a drunk," especially } \\
\text { during the workshift or } \\
\text { immediately after it? }\end{array}$ & 78 & 85 & 19 & 14 & 5 & 3 \\
\hline
\end{tabular}

a For a pairwise comparison of the symptom level and the statistical significance of the difference, see table 8 . Symptoms not listed in table 8 did not differ statistically significantly.

Inquiry to those who had changed employment

A total of 101 answers to the questionnaire were received from the 124 car painters previously employed in the 27 garages involved in this study. A description of the respondents and nonrespondents is presented in fig 1 . The response rate was $90 \%$, ie, only 11 painters did not answer. Of the pensioners, two had retired because of age and four because of disability. There were 39 expainters who were currently employed in jobs free from exposure to organic solvents (group A, fig 1).

Expainters' (group A) answers to the questions concerning acute symptoms during car painting were of a slightly higher frequency than the answers of those 38 men still working as car painters (group B). This result arose when the statistics were calculated as an average sum figure for the six acute symptoms reported more often by the car painters than by their referents (table 7) and when scores 2 and 1 were used for every symptom reported as "often" and "sometimes," respectively. Questions concerning a drunken feeling and misunderstanding of given orders were excluded from this analysis.

The average symptom score of group B was 3.18 (SD 1.9) as opposed to 3.36 (SD 2.1) for group $A$. In addition to other reasons, 26 men (group $A_{1}$, fig 1) $(67 \%)$ of group $A$ mentioned health as an essential reason for leaving car painting work. The mean of their symptom score was 3.81 (SD 2.4), which was consistent with the reported health reasons. Thirteen expainters (group $\mathbf{A}_{2}$, fig 1) stated that they had changed jobs because of better pay or more interesting work. The exposure 
Table 8. Results of a pairwise comparison of the acute symptoms of the 102 age-matched pairs of exposed (car painters) and reference (locomotive engineers and assistants) subjects. ( $A$ : the car painters experienced the symptoms more frequently than the referents; $B$ : the referents experienced the symptoms more frequently than the car painters)

\begin{tabular}{llll}
\hline Symptom & \multicolumn{2}{c}{ Cases } & \begin{tabular}{c} 
Level of \\
significance \\
\cline { 2 - 3 }
\end{tabular} A $\quad$ B difference $a$ \\
(p-value)
\end{tabular}

Irritation symptoms

Are you bothered by itching? $\left(\mathrm{X}_{1}\right)$

$\begin{array}{lcl}36 & 18 & <0.05 \\ 37 & 13 & <0.001 \\ 21 & 6 & <0.01 \\ 28 & 7 & <0.001 \\ 40 & 1 & <0.001 \\ 23 & 5 & <0.01 \\ 46 & 10 & <0.001 \\ 32 & 7 & <0.001\end{array}$

Prenarcotic symptoms

Do you feel nauseated? $\left(X_{2}\right)$

Do you have attacks of vomiting? $\left(X_{3}\right)$

Do you have spells of dizziness? $\left(\mathrm{X}_{4}\right)$

Do you have a drunken feeling? ( $\left.X_{5}\right)$

Are you short of breath? $\left(X_{6}\right)$

Do you feel absentminded or are you buried in your thoughts? $\left(X_{7}\right)$

Do you easily misunderstand orders given to you? $\left(X_{8}\right)$

a Sign test.

Table 9. The pairwise differences in six acute symptom score totals by the duration of exposure.

\begin{tabular}{|c|c|c|c|c|}
\hline \multirow{2}{*}{$\begin{array}{l}\text { Exposure in } \\
\text { whole years }\end{array}$} & \multirow{2}{*}{$\begin{array}{c}\text { Number } \\
\text { of } \\
\text { pairs }\end{array}$} & \multicolumn{3}{|c|}{ Pairwise differences } \\
\hline & & Mean & $\begin{array}{l}\text { Standard } \\
\text { deviation }\end{array}$ & $\begin{array}{l}\text { Standard } \\
\text { error }\end{array}$ \\
\hline$\leq 4$ & 9 & 2.11 & 2.62 & 0.87 \\
\hline $5-9$ & 24 & 0.92 & 2.34 & 0.48 \\
\hline $10-14$ & 26 & 0.81 & 2.28 & 0.45 \\
\hline $15-19$ & 15 & 1.47 & 2.45 & 0.63 \\
\hline $20-24$ & 15 & 3.00 & 3.87 & 1.00 \\
\hline$\geq 25$ & 13 & 2.38 & 3.52 & 0.98 \\
\hline Total & 102 & & & \\
\hline
\end{tabular}

Table 10. The Pearson correlation coefficients of the exposed subjects' acute symptoms, as listed in table 8.

\begin{tabular}{lccccccc}
\hline & $\mathrm{X}_{2}$ & $\mathrm{X}_{3}$ & $\mathrm{X}_{4}$ & $\mathrm{X}_{5}$ & $\mathrm{X}_{6}$ & $\mathrm{X}_{7}$ & $\mathrm{X}_{8}$ \\
\cline { 2 - 8 } $\mathrm{X}_{1}$ & 0.332 & 0.235 & 0.318 & 0.316 & 0.277 & 0.230 & 0.270 \\
$\mathrm{X}_{2}$ & & 0.533 & 0.577 & 0.460 & 0.337 & 0.350 & 0.540 \\
$\mathrm{X}_{3}$ & & & 0.476 & 0.277 & 0.224 & 0.237 & 0.292 \\
$X_{4}$ & & & & 0.335 & 0.378 & 0.213 & 0.340 \\
$X_{5}$ & & & & & 0.362 & 0.232 & 0.230 \\
$X_{6}$ & & & & & & 0.325 & 0.198 \\
$X_{7}$ & & & & & & & 0.455 \\
\hline
\end{tabular}


Table 11. The significance levels of the partial sixth-order correlations between the acute symptoms, as listed in table 8 .

\begin{tabular}{llllllll}
\hline & $\mathrm{X}_{2}$ & $\mathrm{X}_{3}$ & $\mathrm{X}_{4}$ & $\mathrm{X}_{5}$ & $\mathrm{X}_{6}$ & $\mathrm{X}_{7}$ & $\mathrm{X}_{8}$ \\
\cline { 2 - 7 } $\mathrm{X}_{1}$ & $\mathrm{NS}$ & $\mathrm{NS}$ & $\mathrm{NS}$ & $\mathrm{NS}$ & $\mathrm{NS}$ & $\mathrm{NS}$ & $\mathrm{NS}$ \\
$\mathrm{X}_{2}$ & & $* *$ & $* *$ & $* *$ & $\mathrm{NS}$ & $\mathrm{NS}$ & $* * *$ \\
$\mathrm{X}_{3}$ & & & $*$ & $\mathrm{NS}$ & $\mathrm{NS}$ & $\mathrm{NS}$ & $\mathrm{NS}$ \\
$\mathrm{X}_{4}$ & & & & $\mathrm{NS}$ & $*$ & $\mathrm{NS}$ & $\mathrm{NS}$ \\
$\mathrm{X}_{5}$ & & & & & $\mathrm{NS}$ & $\mathrm{NS}$ & $\mathrm{NS}$ \\
$\mathrm{X}_{6}$ & & & & & & $*$ & NS \\
$\mathrm{X}_{7}$ & & & & & & & $* * *$ \\
\hline
\end{tabular}

NS $=$ Not significant $(p>0.05), \quad *=$ almost significant $\quad(0.01<p \leq 0.05)$, ${ }^{* *}=$ significant $(p<0.01), * * * *$ highly significant $(p<0.001)$.

Table 12. Factor pattern of the exposed subjects' acute symptoms, as listed in table 8. Rotated factor matrix (Varimax) of the acute symptoms.

\begin{tabular}{lccccc}
\hline & \multicolumn{5}{c}{ Factors } \\
Variables & 1 & 2 & 3 & 4 & Communality \\
\cline { 2 - 5 } & & & & \\
\hline$X_{1}$ & 0.187 & 0.199 & 0.431 & 0.113 & 0.274 \\
$X_{2}$ & 0.579 & 0.394 & 0.392 & 0.038 & 0.646 \\
$X_{3}$ & 0.669 & 0.170 & 0.145 & 0.074 & 0.503 \\
$X_{4}$ & 0.639 & 0.134 & 0.314 & 0.192 & 0.563 \\
$X_{5}$ & 0.219 & 0.121 & 0.610 & 0.128 & 0.451 \\
$X_{6}$ & 0.189 & 0.154 & 0.384 & 0.444 & 0.405 \\
$X_{7}$ & 0.093 & 0.589 & 0.155 & 0.302 & 0.471 \\
$X_{8}$ & 0.281 & 0.673 & 0.182 & 0.034 & 0.567 \\
\hline
\end{tabular}

time of group A varied from less than 1 to $26 \mathrm{a}$; the median was $4.1 \mathrm{a}$. The exposure times varied from less than 1 to 26 a (median 4.5) in group $\mathrm{A}_{1}(\mathrm{~N}=26)$ and 0-16 a (median 3.1$)$ in group $A_{2}(N=13)$. The corresponding figures of group $B$ were from less than 1 to 23 a (median 9.3).

\section{Discussion}

Inquiry to those who had changed employment

The aim of the inquiry directed towards expainters was to determine whether selection influenced the symptom picture of current car painters.

The inquiry revealed that the personnel records of former employees are often insufficient with respect to new employment. Only 52 of the 101 respondents had actually changed vocations and every fourth (13) of the 52 had remained a painter although not a car painter. Expo- sure to organic solvents had apparently not influenced job turnover in this group. Thirteen (group $\mathrm{A}_{2}$ ) of the 39 expainters did not mention health as a reason for changing jobs. The other 26 expainters (group $A_{1}$ ) mentioned health or occupational hazards in addition to other reasons for changing jobs.

The symptom frequencies of the $39 \mathrm{ex}-$ painters (group A) were of a slightly higher level than those of the current car painters (group B). Still, the time intervals between the termination of exposure and the inquiry diminish the reliability of the expainters' answers in comparison to those of the current painters (group B). However, this irreliability is apt to lower the symptom frequency rather than increase it. The relatively high symptomfrequency level of the expainters who had mentioned health or occupational hazards as important reasons for turnover (group $A_{1}$ ) supports the reliability of the answers concerning the reasons for leaving car painting. Sixty-seven percent of all those 
(group A) who had actually changed vocations had, during the relatively short times of exposure, experienced exposure to solvents as unhealthy or hazardous. Therefore it seems that job turnover had diminished rather than added to the symptom frequency of the car painters in the actual study $(\mathrm{N}=102)$.

The dependence of the relative level of symptoms on the duration of the exposure (table 9) supports the foregoing statements. The decrease in the relative symptom level from the first duration group to the following two, 5-9 a and 10-14 a, strengthens the presence of the selective effect. The increase in later exposure years hints towards diminishing possibilities for job turnover.

It is also possible that a longer exposure time is one explanation for the increase of the relative level of symptoms in the older age groups.

\section{Comparison of the exposed and reference groups}

The comparability of exposed and reference groups is usually a difficult problem in epidemiologic studies. This issue has been discussed in an earlier report on another phase of this study (8), but some remarks are relevant in this context also. Both the car painters and the locomotive engineers and assistants were studied in cooperation with the labor unions. The study was so designed that both categories experienced their role as being "the group under study," not the reference group. Therefore bias caused by different attitudes towards the study seems unlikely.

Kirscht (14) has reviewed the factors influencing the results of symptom surveys made with questionnaires. He stated that the response is influenced by cognitive factors such as the recency, frequency, and awareness of symptoms and motivational factors such as the willingness of the respondent to report the information and the perceived consequence of reporting. Kirscht thinks that a questionnaire is useful in examining the behavioral aspects of illness. In the case of the present study the "illness," ie, the possible harmful effects of exposure to organic solvents, is characteristically a behavioral one, and this study has pointed out that some symp- toms are possibly typical signs of the effects of organic solvents on the nervous system.

The groups of car painters and engineers did not differ with respect to their alcohol consumption, their use of medicines, or their smoking habits. It is a known fact that the questionnaire method underestimates true alcohol consumption. Symmetrical underestimation does not cause bias. If asymmetry would have occurred in this study, it would have been conceivable that the engineers had under-reported their alcohol consumption more because of the nature of their work. Such a bias would decrease the true differences between the groups (ie, negative confounding). However, as reported elsewhere (17), both groups were equal in regard to liver function tests, a finding which speaks in favor of similar alcohol habits. Also the profile and mean of the alcohol consumption of both groups were similar to that of the Finnish working population studied with the same questionnaire method by the Finnish Social Research Institute of Alcohol Studies in 1974 (21).

Neither did slight differences in education seem to affect the results. The performance of the 33 matched pairs tested during military service before the commencement of exposure was equal (8). Still, their test results at the time of this investigation differed in the same manner as those of the rest of the material. The referents had experienced mild head trauma more often than the car painters, but this fact should diminish rather than add to the differences found in symptom frequencies.

Those subjects with the diseases listed in table 4 were not excluded from the study. The symptoms of these workers were symmetrically distributed in both groups and hence would not have caused differences between the groups (if they did not potentiate the effect of the exposure). If reasons for excluding subjects from a study are based on subjective criteria, then observer bias could be a consequence. It was not feasible to make more clinical examinations in this epidemiologic study for the purpose of finding more possible signs or diseases which could have influenced symptoms. However, there is no reason to believe that they would have 
been unevenly distributed among the exposed subjects and the referents. Because the diseases listed in table 4 were not associated (asymmetrically) with the exposure, they could be regarded as effect modifiers only, not confounders, and consequently they did not require control in the analysis.

The locomotive engineers and assistants cannot be considered to be an unusually symptomless group because they work in irregular, interrupted shifts which could also cause symptoms such as fatigue, disturbances in vigilance, and concentration difficulties. Because no essential chemical exposures were found in a study of locomotive engineers' work conditions (11) and the symptoms of the referents represent "background noise" comparable to that of the car painters, the group differences found can be interpreted as having arisen from exposure to organic solvents.

Symptom survey of the car painters and the referents

The main subjective symptoms characterizing the car painter group in general were fatigue, concentration difficulties, and disturbances in vigilance (tables 5 \& 6). These symptoms are congruent with symptoms previously reported by Lindström (19), Lajer (18), Hane et al (10), Gregersen et al (in demented expainters) (7), and Knave et al (15).

Irritation symptoms and "prenarcotic" symptoms during the workday prominently differentiated between the car painters and the referents (tables $7 \& 8$ ). The high statistical difference in the question "Do you easily misunderstand orders given to you?" relates partly to the demands of the work. The orders given to locomotive engineers must be specific and clear because of traffic safety. In contrast the orders given to car painters could be less specific or inadvertently indeterminate. For the referents the same type of situation arises for the question concerning a "drunken feeling" during the workday, and it could be expected that locomotive engineers would not answer yes to this question.

Prenarcotic symptoms from short-term exposure or exposure peaks have also been suspected to exist in exposure to organic solvents $(7,9,15,16,18,23)$. Thus the symptoms found in the group comparison in this study are congruent with symptoms previously connected with exposure to organic solvents, but the exposure of these car painters had been quite low with respect to the TLVs recommended in Finland - an average of about one-third of the TLVs. However, the solvent concentrations may exceed the TLVs during short periods $(5-15 \mathrm{~min})$. It is possible that the exposure has been higher in the past. The fact that the solvents have been the same for about 20 a, ventilation installations about $10 \mathrm{a}$, and the car repair garages' median age was 15 a suggests that there cannot be great differences in the exposure measured in this study and, say, that of 10 a earlier. A recent Swedish study also came to the same conclusion (5). One should keep in mind that the sum percentage is calculated if it is assumed that the effects of solvents would be additive (1). It is also possible that the combined effects of different solvents are potentiative.

\section{Associations between the acute symptoms}

Itching had no confirmed connections with other symptoms, a finding congruent with the low communality of this symptom (table 11). This result was consistent with the nature of this symptom and supports the reliability of the given answers.

The symptoms appearing together in the second complex describe concentration difficulties well and are hypothesized to exist simultaneously. Strong nausea is often followed by attacks of vomiting and dizziness. In other individuals or in lower exposure an association between nausea and a drunken feeling or misunderstanding of given orders are clinically logical, and they also support the reliability of the individual answers.

The results of the association analyses confirm that the acute symptoms were interrelated for individuals just as the symptom complexes described in the earlier literature $(4,5,7,9,12,15,18)$. This finding indicates that the questions were, for the most part, carefully answered. 


\section{Final remarks}

It is always difficult to draw causality conclusions in a prevalence study like the present one, but the results suggest that the differences in symptom frequencies between the exposed subjects and the referents and the associations of the symptoms are caused by exposure to a mixture of organic solvents. As stated in the psychological part of this study (8), the subjective symptoms which differentiated the exposed subjects and the referents the most markedly corresponded to the psychological findings. The results of the other parts of the study, namely, the findings of ophthalmological and neurophysiological disturbances $(25,26)$ also support the view that exposure to organic solvents affects the health of car painters. It is remarkable that the exposure was only one-third of the current Finnish combined TLV, which is based on the ACGIH recommendation published in 1971. But these TLVs are administrative recommendations, not health-based criteria.

\section{Acknowledgments}

I wish to thank E Järvinen, MSc, and Ms $P$ Fahlström for carrying out the statistical analyses.

The study has been financially supported by the Yrjö Jahnsson Foundation.

\section{References}

1. American Conference of Governmental Industrial Hygienists. Threshold limit values of airborne contaminants adopted by the American Conference of Governmental Industrial Hygienists for 1971. Cincinnati, OH 1971.

2. Arlien-Søborg P, Bruhn P, Melgaard B. Det kroniske malersyndrom: Toksisk betinget demens hos malere. Ugeskr laeg 140 (1978) 1645-1649.

3. Capellini A, Alessio L. L'eliminazione urinaria di acido ippurico in operai esposti a toluolo. Med lav 62 (1971) 196-201.

4. Cianchetti C, Abritti G, Perticoni G, Siracusa A, Currade F. Toxic polyneuropathy of shoe-industry workers. J neurol neurosurg psychiatry 39 (1976) 1151-1161.

5. Elofsson S-A, Gamberale $\mathrm{F}$, Hindmarsch $\mathrm{T}$, Iregren $\mathbf{A}$, Isaksson $\mathbf{A}$, Johnsson I, Knave B, Lydahl E, Mindus P, Persson H, Philipson B, Steby M, Struwe G, Söderman
E, Wennberg A, Widen L. En epidemio-logisk undersökning av yrkesmässigt exponerade bil- och industrilackerare. Läkartidningen 46 (1979) 4127-4148.

6. Greenburg L, Mayers MR, Heimann $\mathrm{H}$, Moskowitz $\mathrm{H}$. The effects of exposure to toluene in industry. $\mathrm{J}$ am med assoc 118 (1942) 573-578.

7. Gregersen $P$, Mikkelsen $S$, Klausen $H$, Døssing $M$, Nielsen $H$, Thygelsen P. Et kronisk cerebralt malersyndrom. Ugeskr laeg 140 (1978) 1638-1644.

8. Hänninen $H$, Eskelinen $L$, Husman $K$, Nurminen M. Behavioral effects of long-term exposure to a mixture of organic solvents. Scand j work environ health 2 (1976) 240 255.

9. Härkönen H. Relationship of symptoms to occupational styrene exposure and to the findings of electroencephalographic and psychological examinations. Int arch occup environ health 40 (1977) 231-239.

10. Hane M, Axelson O, Blume J, Hogstedt C, Sundel L, Ydreborg B. Psychological function changes among house painters. Scand j work environ health 3 (1977) 9199.

11. Heino $\mathbf{M}$, Ketola $\mathrm{R}$, Mäkelä $P$, Mäkinen $\mathbf{R}$, Niemelä R, Starck J, Partanen T. Work conditions and health of locomotive engineers. Scand $j$ work environ health 4 (1978): suppl 3, 3-14.

12. Hogstedt C, Hane P, Sundell L. Frågeformulär för symptom och hälsokontroll vid lösningsmedelexposition. Abstrakt. Resumèsamling, 27. Nordiske arbejdshygieniske møde i Danmark 20-23 November 1978. Arbejdsmiljøinstitutet och Arbejdstilsynet, Danmark 1978, pp 137138.

13. Kendall MG, Stuart A. The advanced theory of statistics. Vol 2. Charles Griffin \& $\mathrm{Co}$, London 1961.

14. Kirscht JP. Social and psychological problems of surveys on health and illness. Soc sci med 5 (1971) 519-526.

15. Knave B, Olson BA, Elofsson S, Gamberale $\mathrm{F}$, Isaksson A, Mindus $\mathrm{P}$, Persson HE, Struwe G, Wennberg A, Westerholm P. Long-term exposure to jet fuel: II. A crosssectional epidemiologic investigation on occupationally exposed industrial workers with special reference to the nervous system. Scand $\mathrm{j}$ work environ health 4 (1978) $19-45$

16. Knave B, Persson HE, Goldberg JM, Westerholm P. Long-term exposure to jet fuel: An investigation on occupationally exposed workers with special reference to the nervous system. Scand $j$ work environ health 2 (1976) 152-164.

17. Kurppa K, Husman $K$. Liver enzymes of car painters with long-term exposure to a mixture of organic solvents. XIX International Congress on Occupational Health, Dubrovnik, Yugoslavia 1978. Abstract. p 164.

18. Lajer $M$. Investigation of symptoms in house painters at their work sites. Ugeskr laeg 138 (1976) 1225-1230. 
19. Linđström $\mathrm{K}$. Liuotinainealtistuksen vaikutuksista psyykkiseen suorituskykyyn. Institute of Occupational Health, Helsinki 1972. (Työterveyslaitoksen tutkimuksia 73).

20. Lindström K. Psychological performances of workers to various solvents. Work environ health 10 (1973) 151-155.

21. Mäkelä $K$. Taulukoita eri väestöryhmien alkoholin käytöstä vuosina 1972, 1973 ja 1974. Alkoholipoliittinen tutkimuslaitos Helsinki 1975. (Tutkimusseloste no 84).

22. Maroni M, Bulgheroni C, Cassitto MG, Merluzzi F, Gilioli R, Foá V. A clinical, neurophysiological and behavioral study of female workers exposed to 1,1,1-trichloroethane. Scand $j$ work environ health 3 (1977) $16-22$.

23. Oettingen WF, Neal PA, Donahue DD. The toxicity and potential dangers of toluene. $\mathrm{J}$ am med assoc 118 (1942) 579-584.
24. Ogata M, Tomokuni K, Takatsuka Y. Urinary excretion of hippuric acid and $\mathrm{m}$ - or p-methylhippuric acid in the urine of persons exposed to vapours of toluene and $\mathrm{m}$ - or p-xylene as a test of exposure. $\mathrm{Br} \mathrm{j}$ ind med 27 (1970) 43-50.

25. Raitta C, Husman $K$, Tossavainen A. Lens changes in car painters exposed to a mixture of organic solvents. Albrecht von Graefes Arch klin exp Ophthalmol 200 (1976) 149-156.

26. Seppäläinen AM, Husman K, Mårtenson C. Neurophysiological effects of long-term exposure to a mixture of organic solvents. Scand j work environ health 4 (1978) 304314.

27. Wyse DG. Deliberate inhalation of volatile hydrocarbons: A review. Can med assoc j 108 (1973): Jan, 71-74.

Received for publication: 25 October 1979 